\title{
A novel preservation state of Dolerotheca (medullosalean male organ) from the Late Pennsylvanian of the Sydney Coalfield, Nova Scotia, Canada
}

\author{
ERWIN L. ZODROW ${ }^{1 \star}$ AND MARIA MASTALERZ ${ }^{2}$ \\ 1. Palaeobiological Laboratory, Cape Breton University, Sydney, Nova Scotia B1R 1S1, Canada \\ 2. Indiana Geological and Water Survey, Indiana University, Bloomington, Indiana 47405-2208, USA \\ ${ }^{\star}$ Corresponding author: <zzodrovii@gmail.com>
}

Received 6 July 2018 accepted 11 February 2019

\begin{abstract}
A new preservation state for the medullosalean male organ Dolerotheca is exemplified by a detached 31-mm sideritic mold with intact coalified compression from shale from the roof of a coal seam in the Sydney Coalfield, Cape Breton Island, Nova Scotia, Canada. Clearly recognizable in the specimen is the quadripartite campanulum. Furthermore, maceration yielded significant internal information on acellular, cuticular, stomatiferous and pubescent surfaces, and prepollen sacs with grains. Stomata are rare and of the cyclocytic type. The rectangular prepollen sacs occur as doubly paired rows of sporangia that are radially arranged, and contain ellipsoidal prepollen grains $400-520 \mu \mathrm{m}$ long and circular prepollen grains $330-460 \mu \mathrm{m}$ in diameter. The approximate ratio of circular to ellipsoidal grains is 1:2. Regardless of shape, the prepollen grains are attributable to the genus Monoletes. The circular grains bear vestigial trilete marks. Infrared-based functional-group chemistry distinguishes between the cover-type compression state and prepollen grains on the basis of higher aliphatic and oxygenated group contents in the grains. In summary, the specimen represents a novel state of nodular preservation with intact compression. Although the specimen is attributed to the genus Dolerotheca, specific assignment is not possible because of limited preservation and material.
\end{abstract}

\section{RÉSUMÉ}

On peut citer, comme exemple du nouvel état de conservation pour l'organe mâle médullosalien Dolerotheca, un moule sidéritique isolé de $31 \mathrm{~mm}$, avec compression carbonifiée intacte provenant de schiste du toit d'une couche de charbon des terrains houillers de Sydney, dans lîle du Cap Breton, en Nouvelle Écosse, au Canada. Le campanulum quadripartite est clairement reconnaissable dans le spécimen. En outre, la macération a permis d'obtenir d'importants renseignements internes sur les surfaces acellulaires, cuticulaires, stomatifères et pubescentes, ainsi que sur les sacs de prépollen contenant des grains. Les stomates sont rares et de type cyclocytaire. Les sacs rectangulaires de prépollen se présentent sous la forme de rangées de sporanges doublement appariées, disposées radialement et contenant des grains de prépollen ellipsoïdes d'une longueur de 400 à $520 \mu \mathrm{m}$ et des grains de prépollen circulaires de 330 à $460 \mu \mathrm{m}$ de diamètre. Le ratio approximatif entre le nombre des grains circulaires et celui des grains ellipsoïdaux est de 1:2. Indépendamment de la forme, les grains de prépollen peuvent être attribués au genre Monoletes. Les grains circulaires portent des marques de trilètes vestigiales. La chimie des groupes fonctionnels, à base d'infrarouge, établit une distinction entre l'état de compression du type couverture et les grains de prépollen, sur la base de la teneur plus élevée en groupes aliphatiques et oxygénés dans les grains. En résumé, le spécimen représente un nouvel état de conservation nodulaire avec compression intacte. Bien que le spécimen soit attribué au genre Dolerotheca, une assignation spécifique n’est pas possible du fait de la conservation limitée et du matériel.

[Traduit par la redaction]

\section{INTRODUCTION}

The vast majority of plant fossils used in biostratigraphic and anatomic palaeobotanical studies are preserved through compression and permineralization, but neither preservation state alone is capable of telling the complete story of the living plant or its taphonomy (Pacyna and Zdebska 2012). The rarity of reported male organs of seed ferns from the 
Sydney Coalfield likely stems from the fact that they are generally small, 20 to $31 \mathrm{~mm}$ in diameter, and hence easily overlooked in the field. Bell (1938, pl. 34, figs.1-3) referenced only three specimens of the questionable male organ Telangium potieri. An additional specimen described herein augments the three medullosalean male organs previously reported from the Sydney Coalfield by Zodrow et al. (2017a). In contrast to their rare recovery in the Sydney Coalfield, many specimens of compressed male organs have been recorded elsewhere, particularly from British and central European localities (Halle 1933), as well as from the United States (Millay and Taylor 1979; Rothwell and Eggert 1986).

The present study follows up on our initial research on medullosalean male organs from the Sydney Coalfield (Fig. 1; Zodrow et al. 2017a). Here we report on the discovery of such an organ preserved as a sideritic nodule, a first occurrence for the Sydney Coalfield. Although this preservation state is based on the proposed model for organic matter transformation (Zodrow and D'Angelo 2013, fig. 2), the preservation of a structured coalified compression in a sideritic nodule is new. Here we focus on the internal characteristics of the compression and the morphology of the cuticles, the stomatal type, and details of the prepollen sacs, which contain large monolete prepollen grains about 460 $\mu \mathrm{m}$ long. We also discuss the campanulary authigenic- siderite mineralogy. Additional information is based on the use of Fourier transform infrared spectroscopy (FTIR) methods (Zodrow et al. 2017a; and Zodrow and Mastalerz 2018).

\section{SHORT NOTE ON TERMINOLOGY}

Following Dennis and Eggert (1978, p. 133), the adjective "dorsal" is used when referring to the surface nearest to the peduncle or stalk, and "ventral" when referring to the opposite surface. We use this terminology to avoid confusion between upper and lower surfaces, as for example with foliar cuticles. The terms "lobe" and "lobate" are used in a three-dimensional sense, not in a two-dimensional sense as would be used for lobes of leaf margins or leaf bases.

We regard the formation of a compression as a process entailing the transformation of organic matter in conjunction with lithostatic pressure (sedimentary load) to produce a coalified plant fossil with a cuticle (Zodrow et al. 2009).

\section{MATERIAL AND METHODS}

The material from this study, including prepollen grains and slides are reposited in the Palaeobotanical Fossil

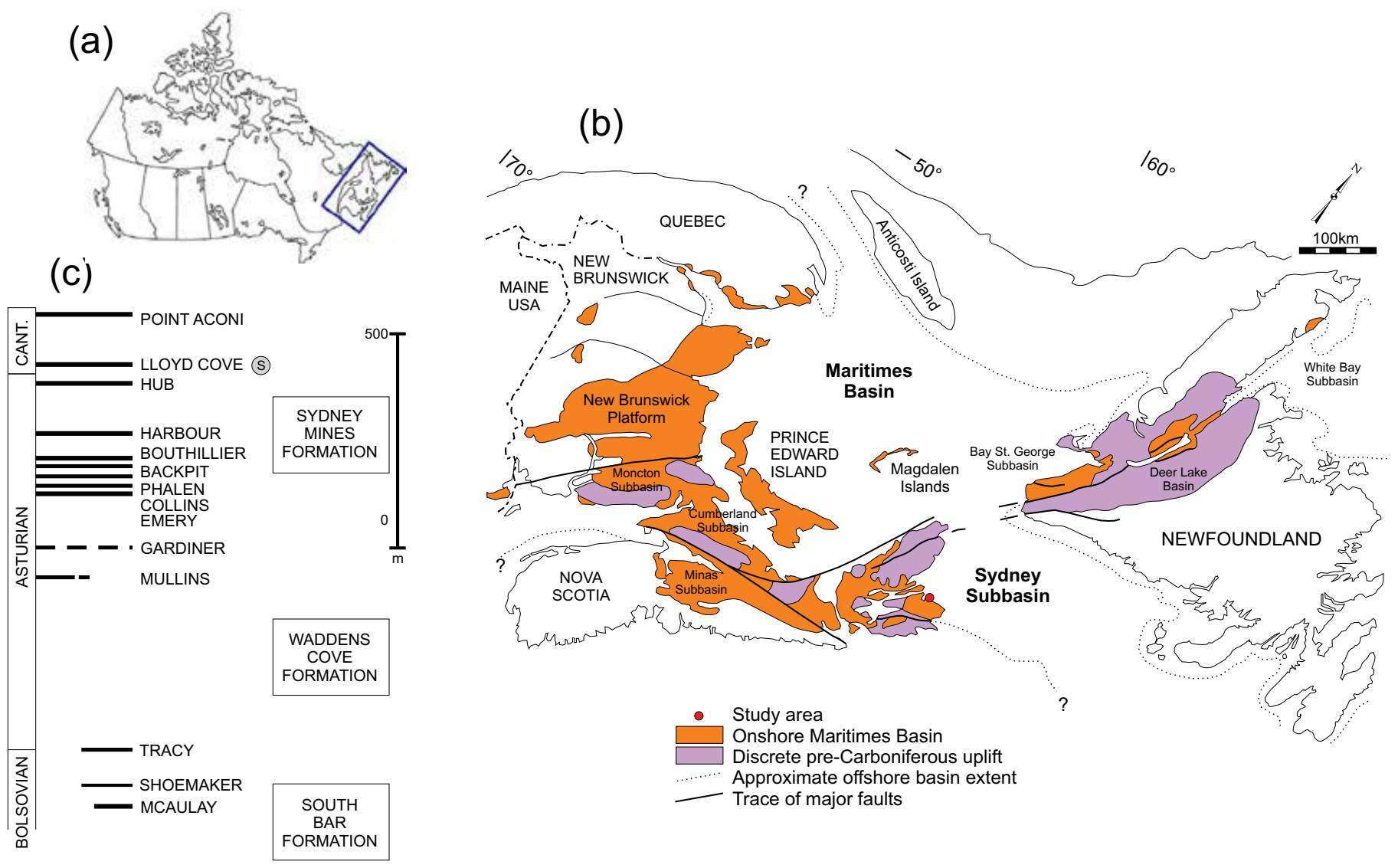

Figure 1. Location map and coal stratigraphy. (a) Regional. (b) Maritimes Carboniferous basins. (c) Coal stratigraphy of Sydney Coalfield; S marks the 4-Z41b sample location at the Lloyd Cove Seam, Sydney Coalfield, Nova Scotia; Cant. = Cantabrian age. 
Collection of Cape Breton University. The nodular mold on which this study is based is accessioned as $4-Z 41 \mathrm{~b}$, and shown in Fig. 2 (Zodrow 2004, p. 1125). It is about 30-31 $\mathrm{mm}$ wide with a negative relief of about $8-10 \mathrm{~mm}$. The senior author chiseled it out of a 1.5 by 1.5 by $0.40 \mathrm{~m}$ waste shale block from the roof shale (about $2 \mathrm{~m}$ thick) of the Lloyd Cove Seam in Brogan's open-pit coal mine near Florence, Cape Breton Island, which closed in 2002 (Figs. $1 \mathrm{~b}-\mathrm{c})$. Embedded in the same sedimentary plane, and near specimen $4-\mathrm{Z} 41 \mathrm{~b}$ (Fig. 2), is a 3.5-cm-long trigonocarpalean ovule, as well as abscised alethopterid pinnules. The roof shale is notable for its rich, well preserved plant-fossil assemblage, among which are taxonomically significant seed-fern associations of the Ca-nadian Carboniferous coalfields. They include a foliage- frond-petiole-trunk-ovule association (Zodrow 2002; Zod-row et al. 2013; D'Angelo and Zodrow 2015, 2016; Zodrow and Mastalerz 2017).
Sample preparation involved the cutting of 3-5 mm-thick rock slices about one centimetre distant from the periphery of the male organ. These slices were used for X-ray diffraction (XRD) analysis. Then, the entire mold was cut out at about $5 \mathrm{~mm}$ from its periphery and digested in hydrofluoric acid (HF 48\%). The compression freed from the sideritic matrix was then washed in distilled water for two days (see State of Preservation below).

Through routine microscopic examination, representative parts of the freed compression were critically selected for maceration using the standard procedure designed for the relatively low degree of coalification $(0.65 \%$ vitrinite reflectance) represented at the Lloyd Cove Seam (Cleal and Zodrow 1989). Cuticles and prepollen grains were mounted on 18 glass-covered microscope slides for study under Nomarski phase-contrast illumination. Considering their harmomegathic properties, size measurements were made on

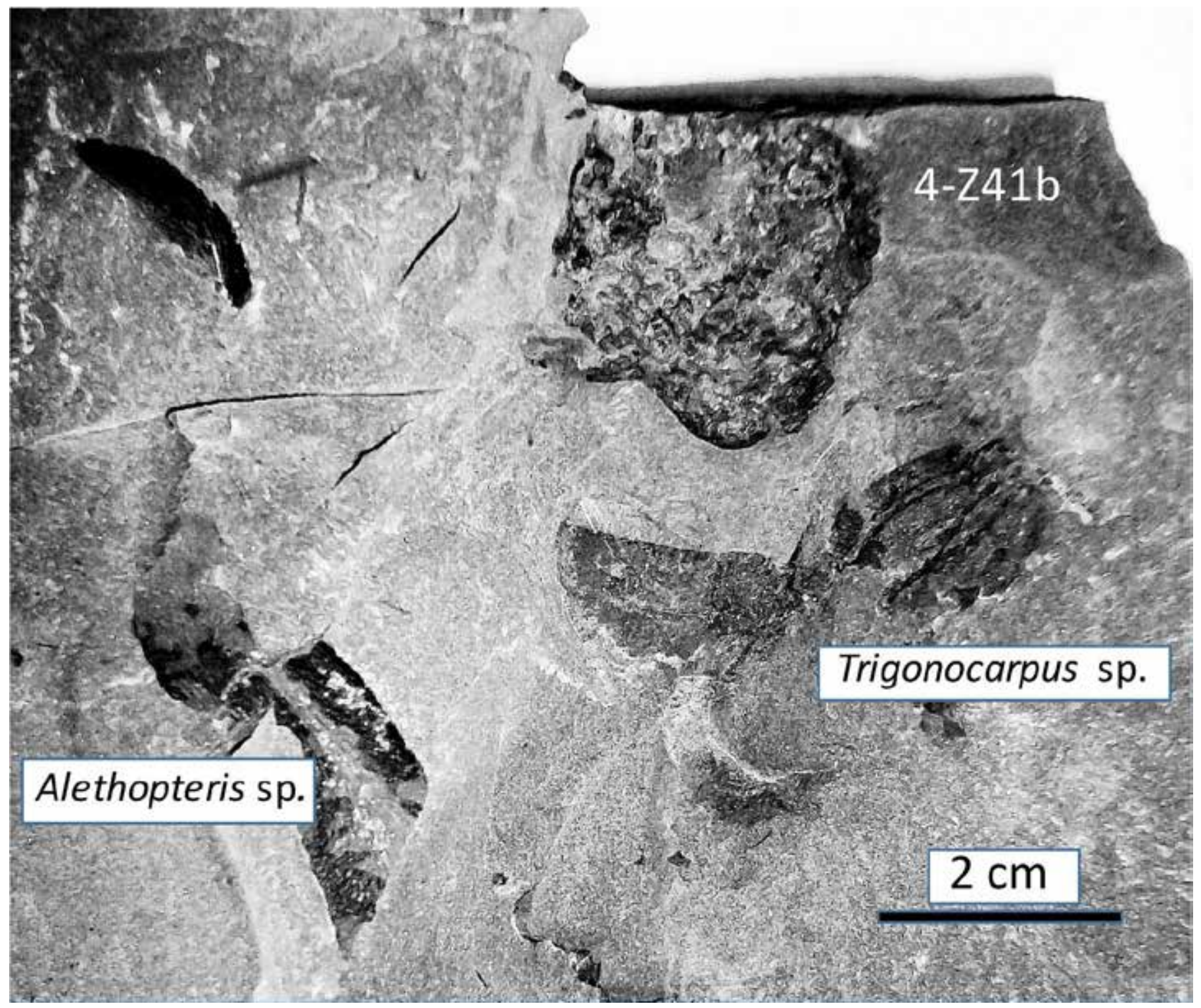

Figure 2. Dolerotheca. 4-Z41b in physical association with a ca. 2-cm long trigonocarpalean ovule and alethopterid foliage. 
rehydrated prepollen grains that probably match the original size and shape better than the shrunken dried grains (Zodrow et al. 2017a, table 2).

Additional information on functional-group content and distribution by methods of $\mathrm{KBr}$ pellets and micro-FTIR were obtained from compression material and prepollen grains.

\section{STATE OF PRESERVATION}

According to Nicholls (1968), four geochemical facies are recognized in Carboniferous coalfields, including the carbonate facies. Even though siderite is representative of the carbonate facies in the Sydney Coalfield, localized sideritic crystallization and nodular formation are also associated with organic matter, similar to the association of pyrite with organic matter in plant fossils of the Sydney Coalfield (Krumbein and Garrels 1952; Zodrow et al. 2017b, p. 121, text-figs. 4A-E). Specimen Z-41b is an example of the latter, as it resulted from a complex geochemical history in an open fluviolacustrine/coastal system (Birk 1990 and references therein).

We attribute the preservation state of specimen 4-Z41b to two successive processes occurring in the carbonate facies of the brackish coastal environment of the slowly subsiding Sydney Basin. One is early diagenetic sideritic crystallization (Berner 1980, equation 5-80), which prevented the collapse of the campanulary mold/cast structure (Fig. 2) of the male organ in subsequent compaction by sedimentary loading. The other is the complex process of compression/ coalification of the substance of the male organ that simultaneously preserved the fine internal features that - in its two-dimensionally compressed state - conforms with the curvature of the mold/cast. Nevertheless, the prepollen sacs maintained aspects of their three dimensional shape and are not flatly compacted.

In summary, the geochemical process that formed our specimen is comparable to Schopf's (1975, table 1) "authigenic" cast/mold scenario. However, what is different in our specimen is the preservation of the fine compression features, which are degraded in contrast to those in Schopf's table 1 . Hence, the stages in the fossilization processes of our specimen and authigenic cementation must be assumed to be different from that involved in Schopf's scenario. Moreover, the fossilization process of the present specimen also cannot be compared with that of Dolerotheca migierii Pacyna and Zdebska 2010, which is an impression in a sideritic nodule without preserved organic material.

The influence of natural maceration (Zodrow and Mastalerz 2009) on areas of the compression of 4-Z41b is notable, and can be seen because of the transparency of the otherwise opaque compression state (Zodrow and D'Angelo 2013, fig. 2). A coalification temperature of about $100^{\circ} \mathrm{C}$, deduced from a vitrinite reflectance value of $\mathrm{R}_{\mathrm{o}} \% 0.65 \%$ (Grist et al. 1995, fig. 5), further promoted the preservation of the micromorphological features.

\section{ANALYTICAL METHODS}

For the KBr-FTIR analysis, $1.1 \mathrm{mg}$ of the compression material was mixed with $250 \mathrm{mg} \mathrm{KBr}$ and analyzed on a Nicolet 6700 spectrometer equipped with a DTGS detector, co-adding 300 scans to produce an infrared (IR) spectrum (Zodrow et al. 2009). The micro-FTIR method was chosen for analyzing single prepollen grains because it is a technique designed for micron-scale specimens in which the radius of analysis is adjustable, and can be as small as $50 \mu \mathrm{m}$ (Mastalerz and Bustin 1993; Chen et al. 2015; Zodrow et al. 2016; Zodrow and Mastalerz 2018). For this analysis, we used the Nicolet 6700 spectrometer connected to a Nicolet Continuum microscope that operated in reflectance mode. A nitrogen-cooled mercury-cadmium-telluride (MCT) detector was used to generate micro-FTIR spectra using a gold plate as background. The OMNIC program was used for spectral deconvolution, and determination of peak integration areas. The resolution for both FTIR methods was $4 \mathrm{~cm}^{-1}$ over a range of $4000-400 \mathrm{~cm}^{-1}$ wavenumber for $\mathrm{KBr}$, and $4000-700 \mathrm{~cm}^{-1}$ wavenumber for micro-FTIR. The interpretive aspect of the IR spectra entailed (1) a qualitative evaluation of spectra, and (2) a semi-quantitative approach based on ratios calculated from absorbance of selected functional groups. In (1), IR-peak assignments to functional groups followed published sources (e.g., Wang and Griffiths 1985 and Rochdi and Landais 1991). In (2), mathematical-spectra processing was applied, which included deconvolution of the bands in the $2800-3000 \mathrm{~cm}^{-1}$ aliphatic stretching region, which enhanced resolution of the band of $-\mathrm{CH}_{3}$ and $-\mathrm{CH}_{2}-$ to obtain aliphatic $\mathrm{CH}_{3} / \mathrm{CH}_{2}$ ratios, and the calculation of other selected functional groups (Colthup et al. 1990; Mastalerz and Bustin 1993; D’Angelo 2006; Petersen et al. 2008). The qualitative (1) and quantitative (2) approaches conformed to our usual analytical $\mathrm{KBr}$-pellet FTIR and microFTIR laboratory protocols, hence the present data can be directly compared with our previously published data (see D'Angelo and Zodrow 2016 for a summary).

\section{RESULTS}

\section{Siderite mineralogy}

A bulk sample (about $75 \mu \mathrm{m}$ grain size), examined under a petrological microscope prior to XRD analysis consisted mainly of light-brown rhomboidal crystals and fragments lacking secondary oxidative alteration. The peaks of the XRD diffractogram (Fig. 3), however, could not be matched with those of the pure phase of $\mathrm{FeCO}_{3}$, but with one of atomic substitution of $\mathrm{Ca}^{+2}$ and $\mathrm{Mg}^{+2}$ for $\mathrm{Fe}^{+2}$ had taken place (e.g., Deer et al. 1992). Corresponding to that prominent peak is the empirical formula $\left(\mathrm{Ca}_{0.1} \mathrm{Mg}_{0.33} \mathrm{Fe}_{0.57}\right) \mathrm{CO}_{3}$; minor components in the bulk sample were probably contaminating silicate minerals, or detrital quartz grains from the enclosing shale. 
Description of the sideritic mold 4-Z41b and compression surfaces, and cuticles

The mold $4-\mathrm{Z} 41 \mathrm{~b}$ is characterized by four broad lobes separated by narrow longitudinal grooves that converge dorsally without observable remnants of a peduncle or stalk. The larger left-side lobe (Fig. 2) shows curved rows of paired, rectangular prepollen sacs, clearly seen in Fig. 4, that radiate from the dorsal surface to the ventral surface. Halle (1933, p. 46) called such rows "strings of pearls". The prepollen sacs are smallest in the dorsal region and increase in size ventrally. The marginal areas appear smooth, although obtuse termini can be seen faintly; the presence of these termini is confirmed in a coalified fragment that shows them forming a crenate rim with non-branching uniseriate hair about $60-\mu \mathrm{m}$-long (Fig. 5a). Hair typically occurs on the dorsal face of the organ (Schopf 1948, figs. 14C, E-F). The grey-white patches in Fig. 2 show areas on the outside of the mold where siderite is exposed due to the destruction of the compression during coal-mining operations.

Study of the compression in cross-section revealed a layered nature. Two layers were observed, occasionally differentiated by the presence of protruding rectangular-rotund terminal prepollen sacs in one layer and their absence in the other. This is demonstrated by the smoother surface shown in Fig. 5b; this is probably the dorsal surface, although the hair is not observable. Fig. $5 \mathrm{c}$ shows the obverse, or ventral surface, which is marked by imbricated prepollen-sac termini, faintly visible on the lower end. From the perspective of compression, the fragment, which is about $12 \mathrm{~mm}$ wide and $8 \mathrm{~mm}$ long (Fig. 4) probably originated from the larger lobe shown in Fig. 2. Illustrated in Fig. 4 are two rows of doubly paired, contiguous prepollen sacs with in situ sporangia and grains that correlate to the pits in the studied mold (see Halle 1933). The fragmentary row consists of five pairs, where the rectangular prepollen sacs are $1500-1900 \mu \mathrm{m}$ long and $750-880 \mu \mathrm{m}$ wide. It is significant that these prepollen sacs retained their three-dimensional configuration as a result of the stabilizing influence of siderite during mold formation. Furthermore, because the prepollen grains were not shed at the time when the organs dropped off, they are assumed to be developmentally immature, implying a size bias (Table 1).

\section{Maceration products}

For description and discussion purposes, the maceration products from three connected prepollen sacs are subdivided into cuticles, acellular surfaces, prepollen sacs, and prepollen grains. As a result of the three-dimensional preservation, in situ sporangia could be observed, which facilitated the separation of opposite surfaces of a prepollen sac (Figs. 6a-b). These surfaces are shown to be acellular, dense,

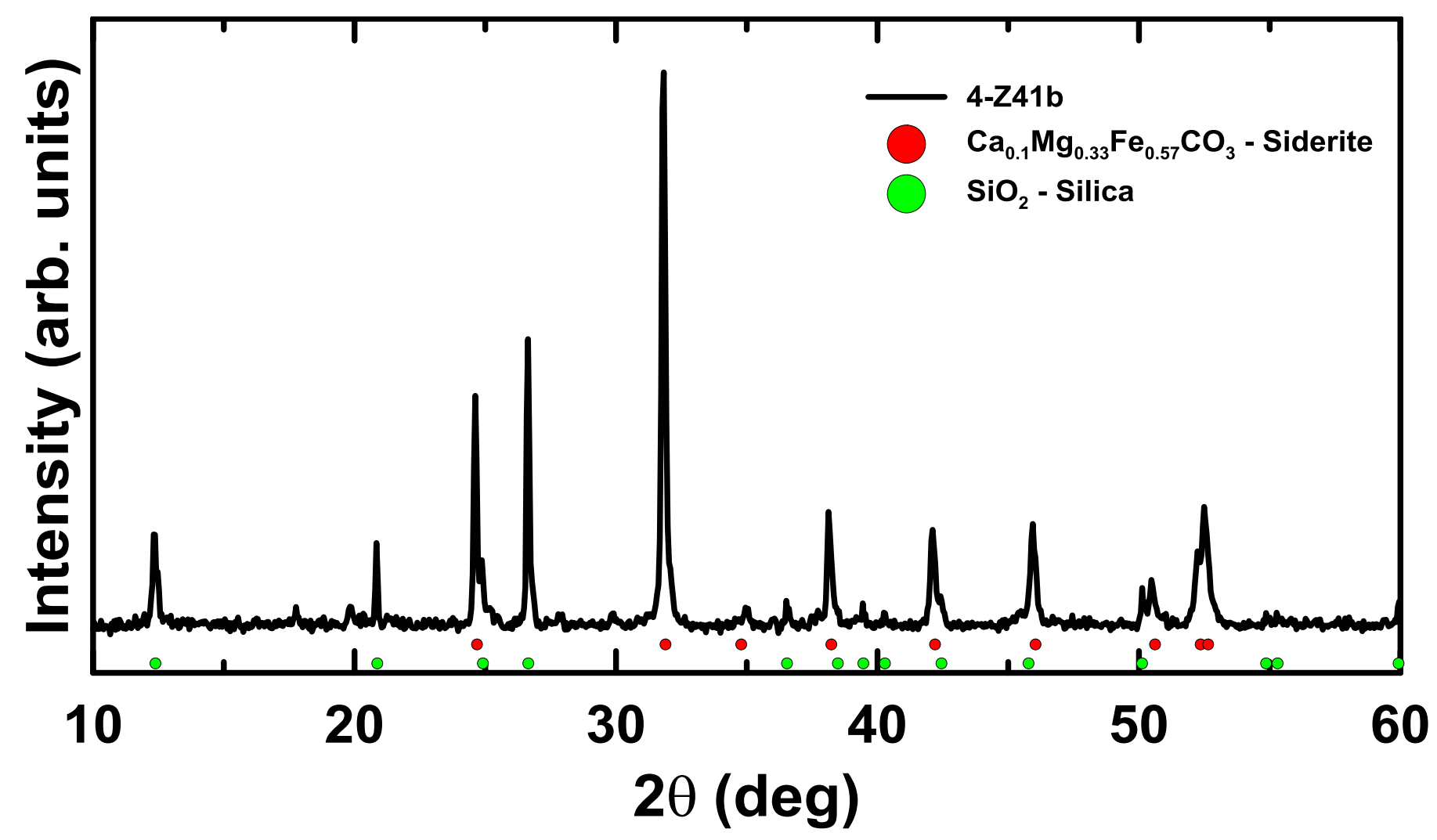

Figure 3. Diffractograph of siderite and its chemical composition. Bruker D8 Advance XRD; scanned from $1^{\circ}$ to $90^{\circ}$, at $0.05^{\circ}$ increment, and 1 second scan time at each increment. 


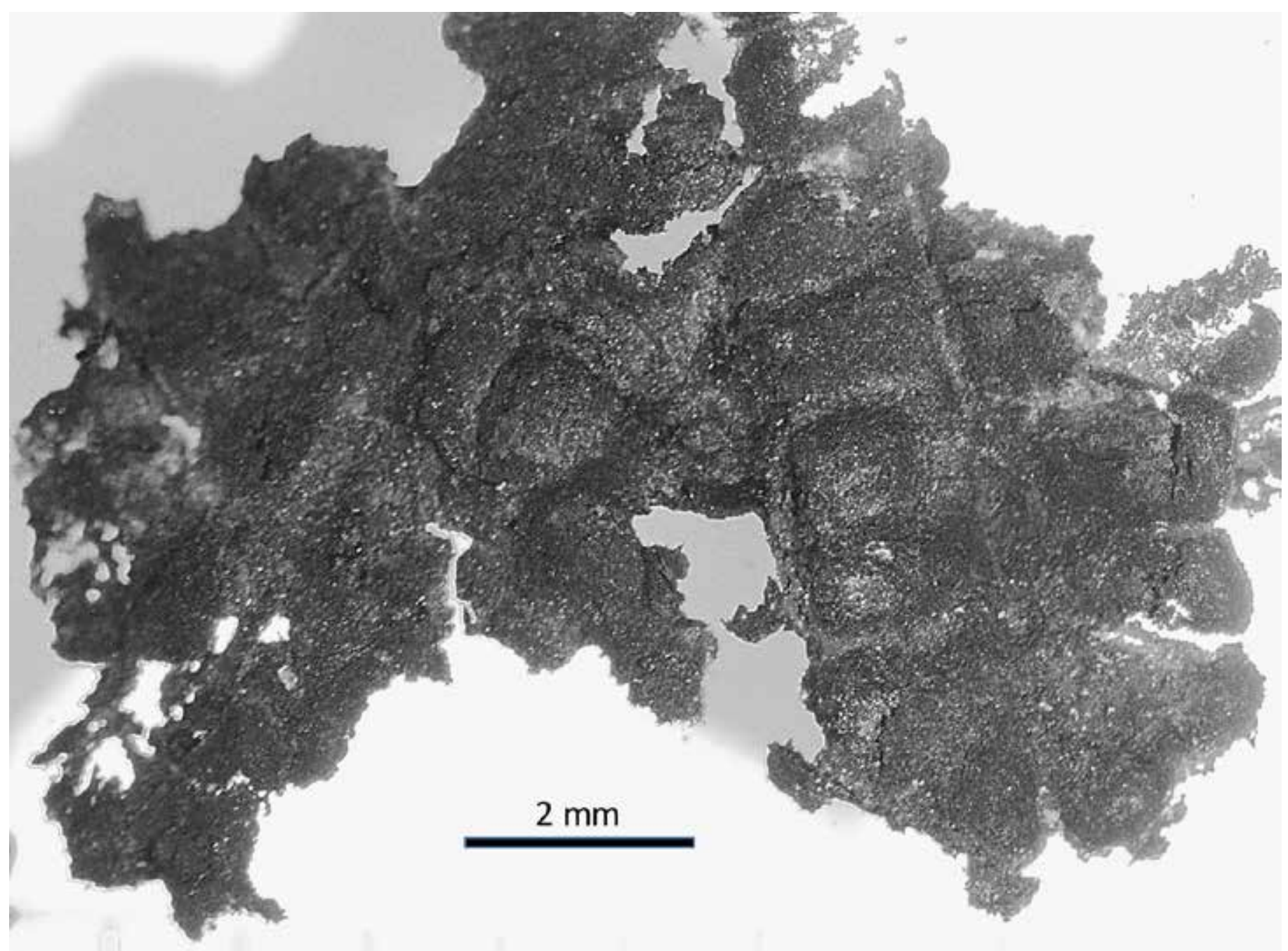

Figure 4. Dolerotheca. A fragmentary double row of coalified, rectangular prepollen sacs organically connected. Preserved reference material.

and interlaced with vascular bundles that could not be fully mapped because of the small number of samples available.

The compressed non-prepollen-sac material is composed of more than one layer; layers could be separated only with difficulty by the "teasing-apart" method used for separating foliar cuticles (Cleal and Zodrow 1989). Loose fragments of surfaces could be separated on the presence or absence of stomata, but the positions of the surfaces in relation to the upper/lower prepollen-sac surfaces (i.e, in terms of the internal structure) could not be ascertained. In some cases, a surface has small, round, cell-like features about $10 \mu \mathrm{m}$ in diameter, with a fragmentary stoma preserved by three neighbour cells that are about $12 \mu \mathrm{m}$ long and $8 \mu \mathrm{m}$ wide (Fig. 6c). In contrasting cases, a cuticular surface (Fig. 6d) shows well-preserved, somewhat rectangular cells ranging from $17 \times 33 \mu \mathrm{m}$ to $33 \times 47 \mu \mathrm{m}(\mathrm{n}=8)$, with straight and prominently cutinized anticlinal walls. A cyclocytic? stoma from that same cuticle (Fig. 6e) has small guard cells $17 \mu \mathrm{m}$ long and $7 \mu \mathrm{m}$ across, surrounded by five distorted wedge- shaped neighbour cells that are 27-50 $\mu \mathrm{m}$ long and about $34 \mu \mathrm{m}$ wide. Stomata associated with acellular surfaces includ the cyclocytic type (Fig. 6f, enlarged in Fig. 6g). The guard cells are about $10 \mu \mathrm{m}$ long and $5 \mu \mathrm{m}$ wide, and the three recognizable and elongate neighbour cells are 40-43 $\mu \mathrm{m}$ long and $20-26 \mu \mathrm{m}$ wide. The stoma (Fig. $6 \mathrm{~h}$ ) has guard cells about $40 \mu \mathrm{m}$ long and $17 \mu \mathrm{m}$ across, and a discernible faint circumscribing oval ring (6-7 $\mu \mathrm{m}$ wide) that could be interpreted either as a stomatal flap or as the bottom tube of the guard cells. This ring is surrounded by faintly visible rectangular to oval neighbour cells that, though visible are 33-40 $\mu \mathrm{m}$ long and 17-27 $\mu \mathrm{m}$ wide. Although only five neighbour cells could be reliably counted, there may be up to twelve. Stomatal density, stomatal index and polar trend could not be determined.

Each prepollen sac contains at least six, and possibly twelve, layers with intact grains, three to four across (perhaps in tetrads). Each layer is separated by thin acellular material with delicate vascular bundles, the latter being 

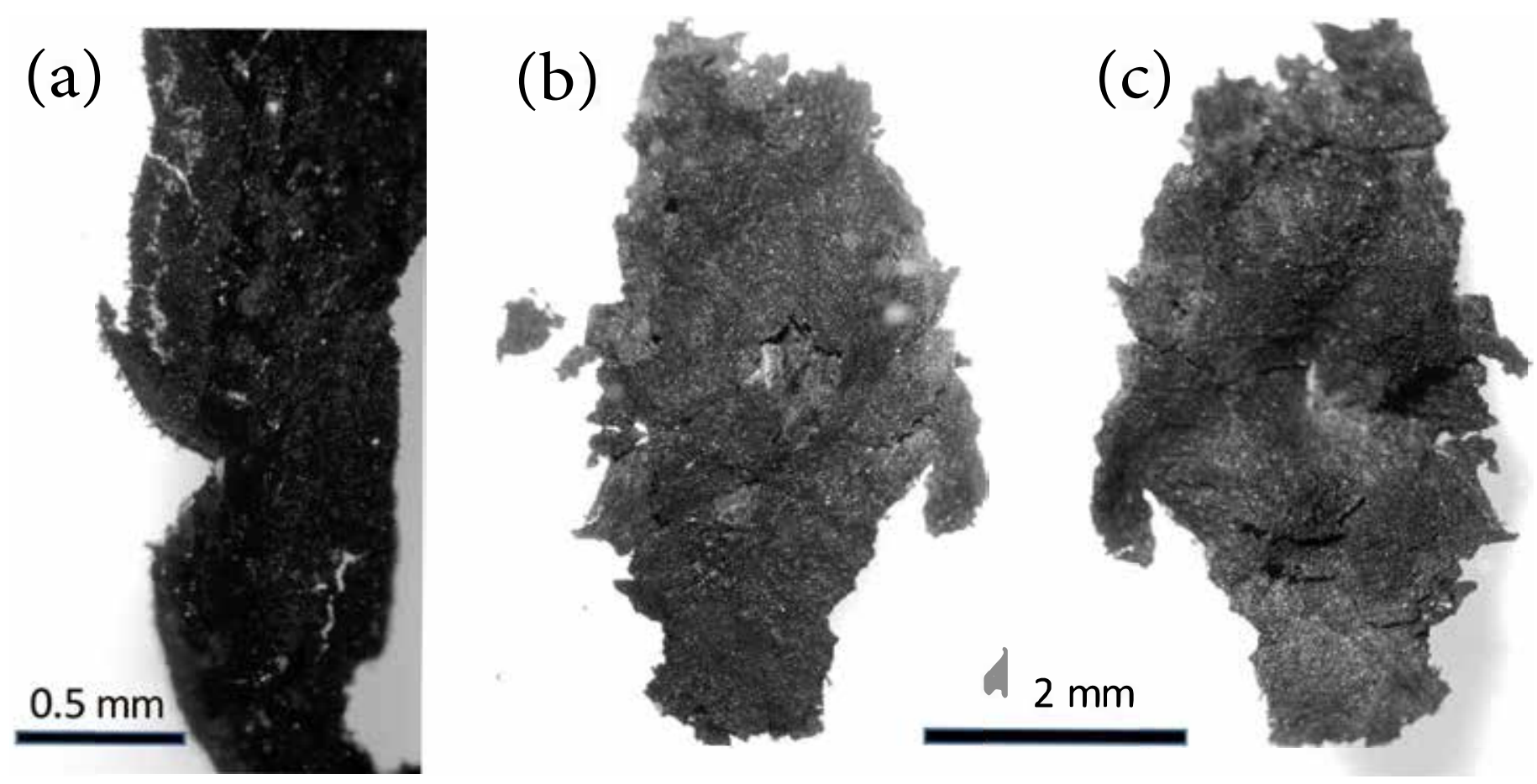

Figure 5. Dolerotheca. (a) Pubescent ventral termini of prepollen sacs. (b) Reverse and (c) obverse surfaces of compression fragment, where pubescence is not visible. All slides temporary.

the most abundant maceration products encountered and probably parenchymatous tissue (Stidd 1981). Among the sporangia recovered, the maximally length is $2 \mathrm{~mm}$; they contain circular and ellipsoidal prepollen grains (Fig. 7a). Figure $7 \mathrm{~b}$ shows a rare example of a circular prepollen grain, $460 \mu \mathrm{m}$ in diameter. At the commissural deflection, branches (17 $\mu \mathrm{m}$ long) of a triradiate mark are clearly visible in the water-inflated samples. Figure $7 \mathrm{c}$ shows an ellipsoidal grain that is $520 \times 380 \mu \mathrm{m}$. Table 1 summarizes grain-size data. Noteworthy is the 1:2 ratio of circular to ellipsoidal grains. The distal surfaces of both prepollen forms are marked by deflected commissural apertures with terminally located triradiate rays $10-13 \mu \mathrm{m}$ long. The proximal surfaces, show vaguely perceptible symmetrical ridges; however, we regard these to be the result of shrinkage and thus not of taxonomic relevance (Zodrow et al. 2017a). Prepollen grains clearly show an alveolate surface structure when immersed in water and magnified at $\times 250$, (e.g., Fig. $7 d$ ).

\section{FTIR functional-groups}

The $\mathrm{KBr}$ spectrum of the compression part of the specimen (Fig. 8) shows a relatively high contribution of aliphatic stretching moieties in the $3000-2800 \mathrm{~cm}^{-1}$ region, and distinct bands in the aliphatic bending region, especially the one with the peak at $1446 \mathrm{~cm}^{-1}$ wavenumber. A prom-inent band of aromatic carbon at $1603 \mathrm{~cm}^{-1}$ wavenumber and a very small shoulder at $1701 \mathrm{~cm}^{-1}$ represent oxygenated groups. Aromatic hydrogen bends are also present, and they are especially distinct in the out-of-plane $700-900 \mathrm{~cm}^{-1}$ region, where all three aromatic bands are present. Hydrogen bends in the aromatic stretching region (3000-3100 $\left.\mathrm{cm}^{-1}\right)$ are of low intensity. All these qualitative characteristics are reminiscent of vitrinite of high volatile bituminous rank (e.g., Walker and Mastalerz 2004, fig. 5). Semi-quantitatively, the compression is characterized by a higher $\mathrm{CH}_{2} / \mathrm{CH}_{3}$ ratio (2.78) compared with the vitrinite of high volatile bituminous coal, where $\mathrm{CH}_{2} / \mathrm{CH}_{3}$ ratios were within a range of 1.25 to 1.32 , suggesting longer and less branched aliphatic chains for the compression.

Micro-FTIR spectra from a prepollen grain are very different from those of the compression (Fig. 9). The most prominent bands of the $1600-1800 \mathrm{~cm}^{-1}$ region belong to oxygenated groups. Aromatic carbon at $\sim 1600 \mathrm{~cm}^{-1}$ is much less distinct and is overwhelmed by neighbour oxygenated groups. Aromatic hydrogen bands in either the aromatic stretching region or the out-of-plane region are almost undetectable, whereas aliphatic bands in the stretching region are of high absorbance. This results in very low aromaticity $(0.00086,0.0031)$, lower ratio of aliphatic stretching bands to oxygenated groups and aromatic carbon $(\mathrm{Al} / \mathrm{Ox})$, and a much higher $\mathrm{CH}_{2} / \mathrm{CH}_{3}$ ratio compared to that of the compression. We note, however, that these ratios vary significantly between the individual sampling positions on the prepollen grain, as shown in Fig. 9, due to either a different original chemistry or to the influence of secondary processes such as oxidation. 
Table 1. Statistics of ellipsoidal and circular prepollen grains of 4-Z41b specimen. Raw data ${ }^{\mathrm{a}}$ : number of divisions at $\times 250$ magnification.

\begin{tabular}{|c|c|c|}
\hline \multicolumn{2}{|c|}{ Elliptical prepollen } & \multirow{2}{*}{$\begin{array}{c}\text { Circular prepollen } \\
\text { diameter }\end{array}$} \\
\hline Length & width & \\
\hline 400 & 333 & 333 \\
\hline 400 & 144 & 333 \\
\hline 466 & 323 & 340 \\
\hline 466 & 366 & 346 \\
\hline 473 & 366 & 350 \\
\hline 480 & 366 & 353 \\
\hline 486 & 300 & 360 \\
\hline 486 & 393 & 366 \\
\hline 493 & 413 & 380 \\
\hline 500 & 366 & 383 \\
\hline 500 & 400 & 393 \\
\hline 500 & 406 & 393 \\
\hline 520 & 380 & 400 \\
\hline \multicolumn{2}{|c|}{ Mean: } & 400 \\
\hline 475 & 377 & 400 \\
\hline \multicolumn{2}{|c|}{$(\mathrm{n}=13)$} & 400 \\
\hline & & 413 \\
\hline & & 413 \\
\hline & & 416 \\
\hline & & 420 \\
\hline & & 460 \\
\hline & & Mean: $384 \mu \mathrm{m}$ \\
\hline & & $(\mathrm{n}=21)$ \\
\hline
\end{tabular}

\section{DISCUSSION}

\section{Micromorphology}

A theoretically predictable but heretofore unrecognized state of nodular preservation of a medullosalean male organ is here reported from the carbonate facies of the Canadian Sydney Coalfield. The quadripartite configuration, preserved by siderite in three dimensions, suggests that the campanulum originally had a squat bell shape. Whether this confirms the theory of Dennis and Eggert (1978, fig. 45), involving a four-part campanulum based on independent synangial structures, refuted by Stidd (1990), is debatable. However, Zodrow et al. 2017a, figs. 2 and 14) previously reported three compressed medullosalean male organs with tripartite campanuli with a more elongate configuration from the Sydney Coalfield. This suggests a diversity of campanulary configuration.
In terms of the internal configuration, we report fragmented rows of paired prepollen sacs preserved through compression, whose pitted imprints on the sideritic mold are arranged in radial fashion from the dorsal to the ventral surfaces. Disk-like compressions/impressions with radial pits are distinctive of Dolerotheca Halle 1933 (e.g., Halle 1933 , p. 47, who cited the specimens illustrated as Renault 1896, pl. 9, figs. 5-6; Schopf 1948, p. 719, 721; Cridland et al. 1963, pl. 22, fig. 50; Gillespie and Clendening 1967, pls. 1-3; and Pacyna and Zdebska 2010). In terms of permineralization, however, these rows of paired prepollen sacs ("pit strings") are equivalent to structures seen in a transverse section of specimens of Dolerotheca (Halle 1933; Schopf 1948, pl. 105, fig. 1).

In contrast with the digitiformis arrangement of synangia in the Dolerotheca-like specimens (Zodrow et al. 2017a), the specimen described here is characterized by elongate sporangia. These contain a relatively large proportion of circular prepollen grains relative to ellipsoidal ones, the former commonly showing a triradiate mark related tetrad separation, and thus non-functional, as is the case for prepollen (Schopf 1948, p.701).

The scarcity of compression material in the specimen studied, attributed to erosion by coal-mining activity, is reflected in the small number of different cuticular/acellular surfaces observed. In contrast, Schopf (1948) documented a number of differently structured cuticles in permineralized Dolerotheca specimens. The stomatal type identified on the specimen studied compares with that of the Dolero-thecalike organ [see Zodrow et al. 2017a, fig. 6D(2)], and with that reported previously for the coal ball Sullitheca dactylifera by Stidd et al. (1977). Schopf (1948) did not observe stomata. The surface markings, ellipsoidal/circular shapes, and very large size of the in situ prepollen grains fit the concept of Monoletes Schopf 1936 nom. cons.

In taxonomic terms, the campanulary shape, structural arrangement of prepollen sacs in paired rows, and the nature of the in situ prepollen grains fit the generic concept of Dolerotheca (Stidd 1981; Rothwell and Eggert 1986; Stidd 1990). However, specific assignment is not warranted based on a single fragmentary specimen.

\section{Spectrochemical comparison}

Micro-FTIR results of this study compare closely with the $\mathrm{KBr}$ results of the prepollen grains of Dolerotheca-like prepollen organs (Zodrow et al. 2017a, fig. 12). The dominance of oxygenated groups, prominence of aliphatic stretching bands and indistinct aromatic $\mathrm{H}-\mathrm{C}$ bands both in the stretching and in the out-of-plane region are all characteristic of prepollen. The main difference detected in the qualitative analysis of the spectra is a higher contribution of aromatic carbon in the Dorotheca-like prepollen organs when compared to the prepollen of the current study. Comparison of the functional-group ratios indicates a slightly lower $\mathrm{Al} / \mathrm{Ox}$ ratio for the current grain $(0.20-0.29)$ compared 


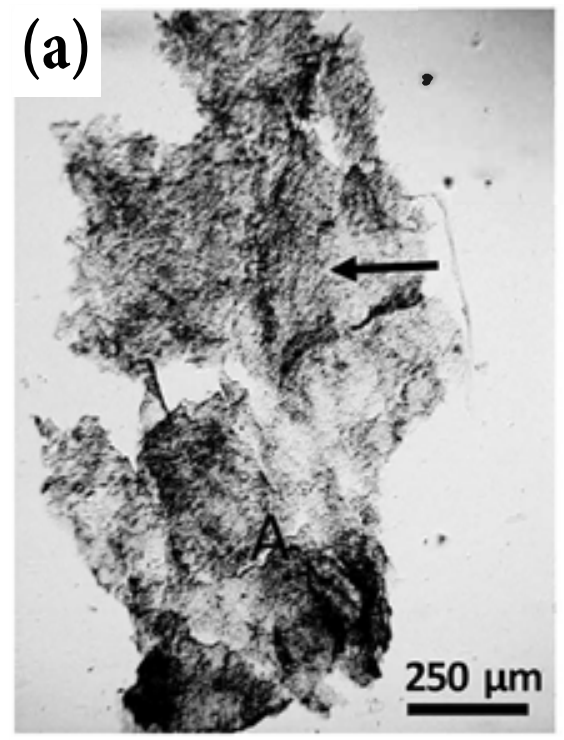

(b)
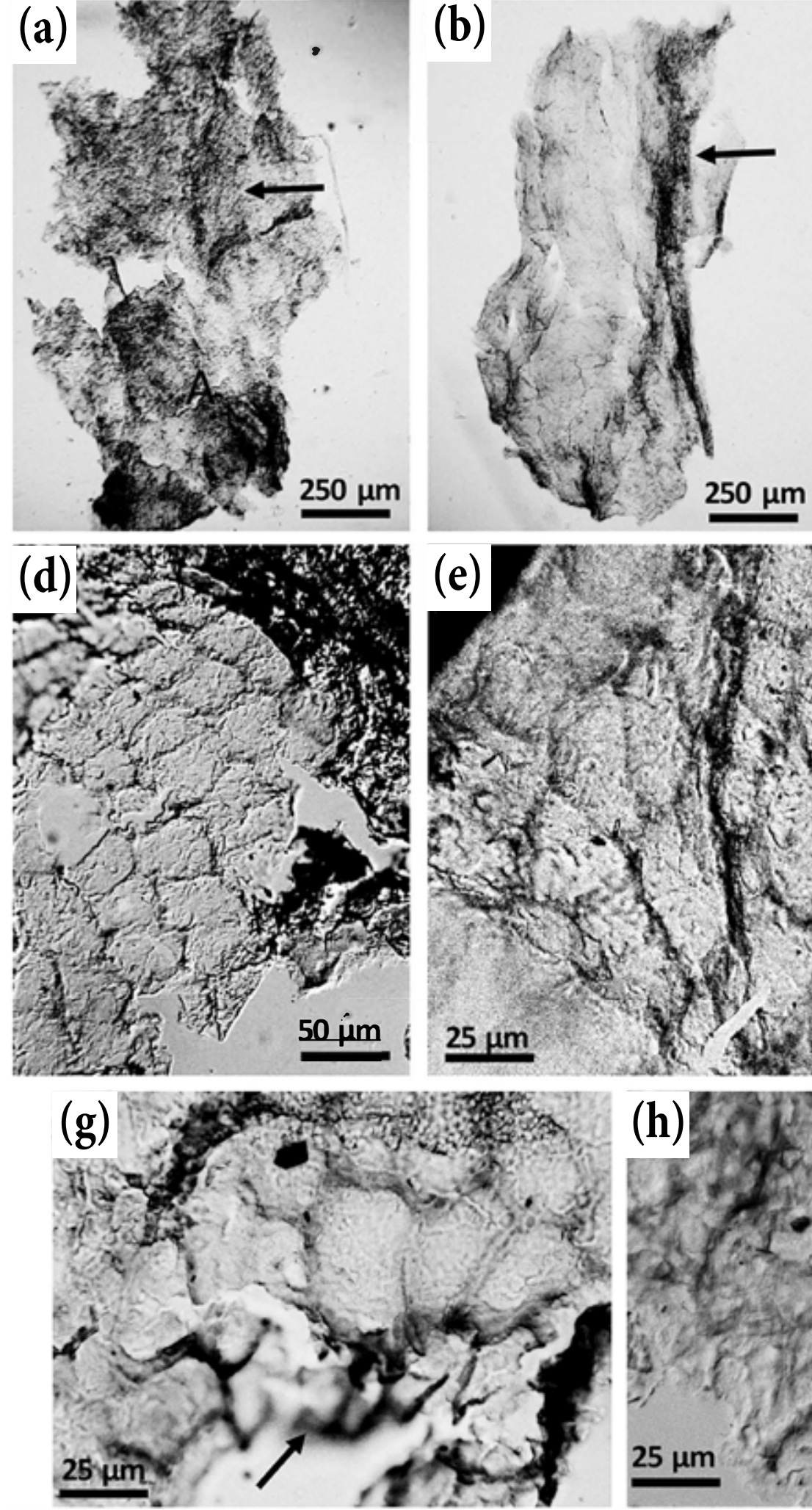
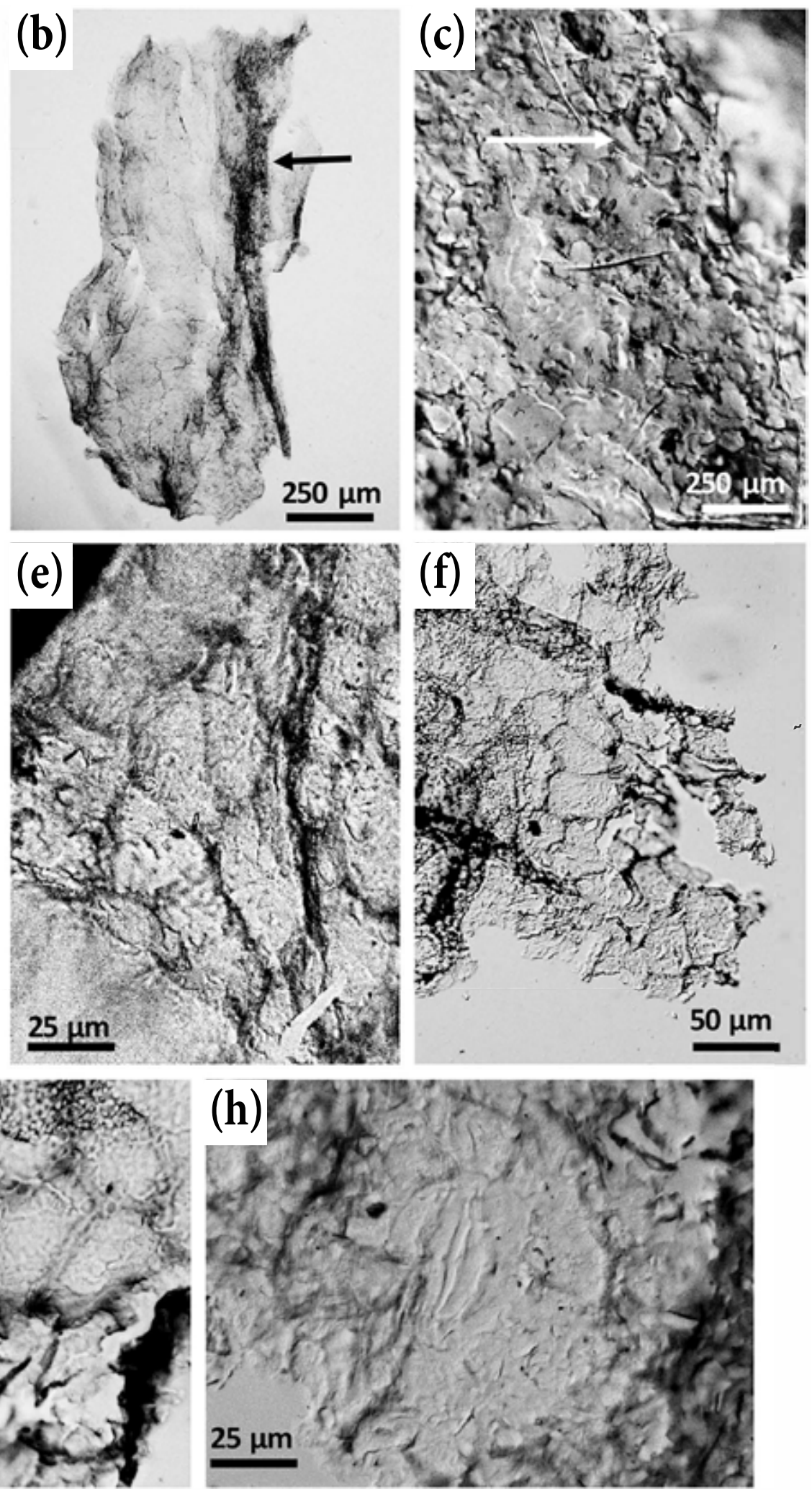

Figure 6. Dolerotheca. Surface (a) and surface opposite (b), respectively, of a prepollen sac as in Fig. 5, with vascular bundles (arrows). (c) Cuticular surface with a fragmentary stoma (arrow), preserving only three neighbour cells. (d) Cuticle with large square-like cells. (e) Stoma with 5 ? neighbour cells from cuticle shown in $\mathrm{d}$. (f) Two closely spaced stomata with elongate, oval neighbour cells. (g) Enlargement of (f), where the very small bean-shaped guard calls (arrow) are faintly pre-served. (h) Stoma with relatively large guard cells. Slide documentation: 4-Z41b "1"/1, 4-Z41b "1"/2, 4-Z41b "1"/2, 4Z41b “5”/15, 4-Z41b “5”/15, 4-Z41b "2"/7, 4-Z41b "2"/7, and 4-Z41b " 5 "/12, respectively. "1" to " 5 " refers to documented indi-vidual fragments. 

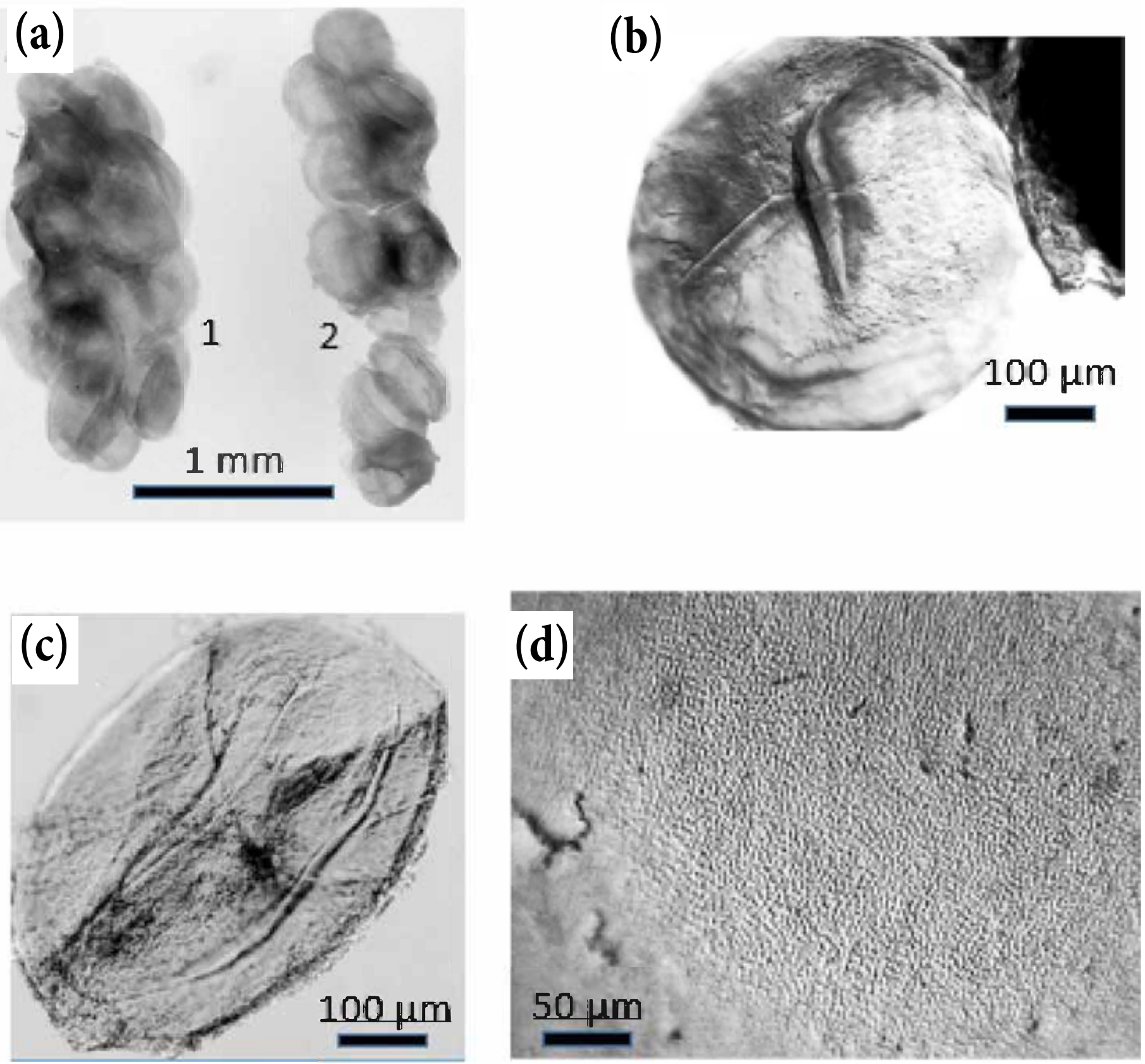

Figure 7. Dolerotheca. (a) Sporangia from one prepollen sac, where "1" is multilayered, and " 2 " a single layer. (b) The largest, $460 \mu \mathrm{m}$, circular trilete "spore" in situ. (c) Ellipsoidal prepollen grain, $500 \mu \mathrm{m}$. (d) Proximal prepollen-grain surface with honeycomb structure. Slide documentation: 4-Z41b “1"/4b, 4-Z41b “1”/1, 4-Z41b "1"/5a, respectively.

to the Dolerotheca-like prepollen (0.34), suggesting more advanced oxidation for the grain studied. In turn, a higher $\mathrm{CH}_{2} / \mathrm{CH}_{3}$ ratio (5.5-8.4 versus $\sim 4$ for the Dolerothecalike prepollen), suggests higher and straighter aliphatic chains for the prepollen studied here. We suggest, however, that these spectrochemical differences could be due to diagenesis (e.g., Lis et al. 2005), although some differences, especially the length of the aliphatic chains, may also have resulted from subtly different taphonomic influences.

\section{CONCLUSIONS}

Relatively few reports of coalified and permineralized medullosalean male organs have appeared in the literature since the late 1970s, and the 4-Z41b specimen described here is one of the few exceptions concerning compressions. The significance of this specimen rests on the preservation of a three-dimensional quadripartite campanulum in a sideritic matrix with compression material, which provided sufficient diagnostic information for grouping it with 
Dolerotheca. Specific assignment is not possible with such insufficient material.

Overall, the discovery of a medullosalean male organ in a state of preservation not previously reported in the litera- ture enhances not only the significance of the medullosalean Lagerstätte at the Lloyd Cove Seam of the Sydney Coalfield; it also illustrates the variety of preservational possibilities in the Carboniferous fossil record.

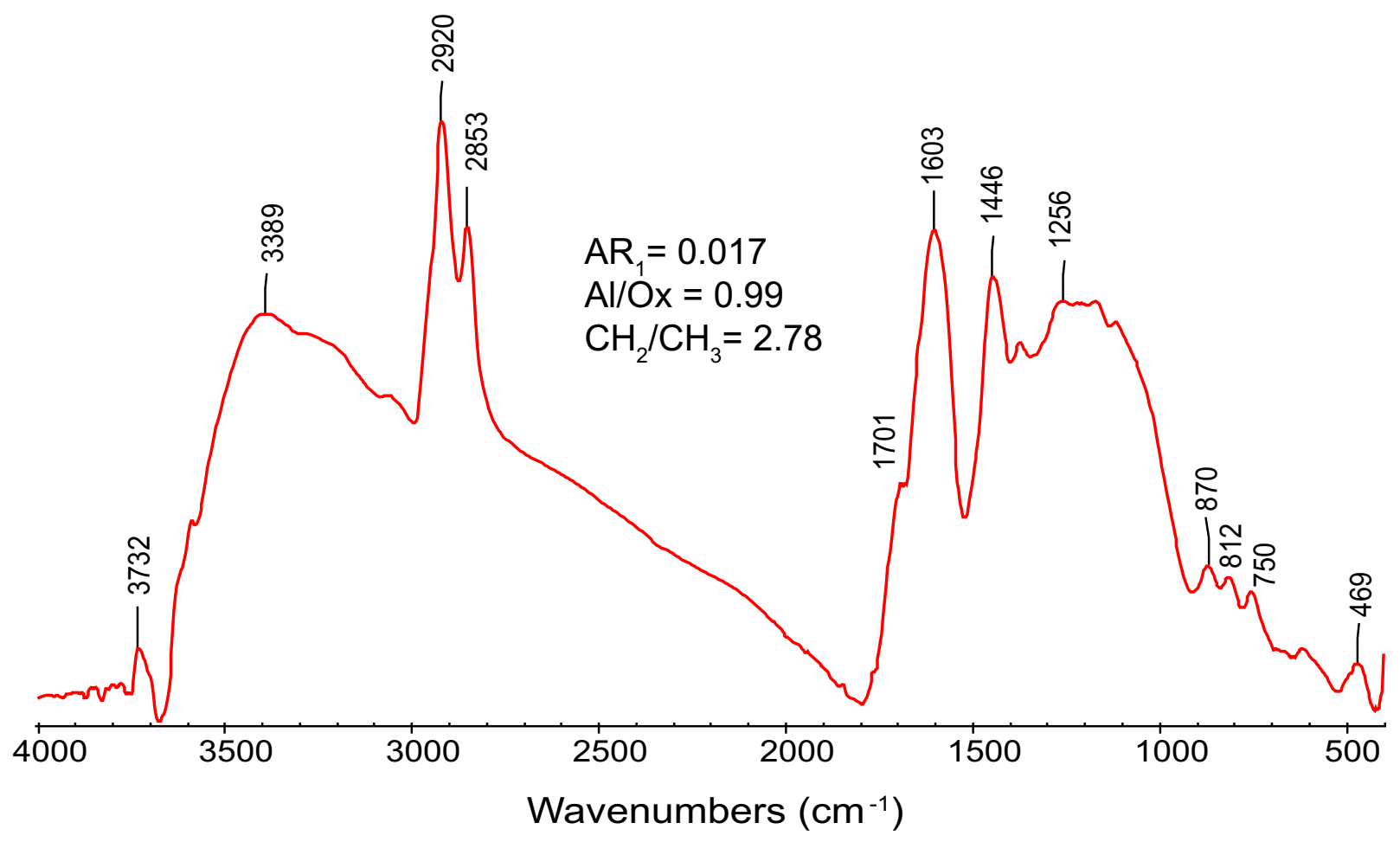

Figure 8. 4-Z41b. KBr-pellet, infrared spectrum of compression. See Text.

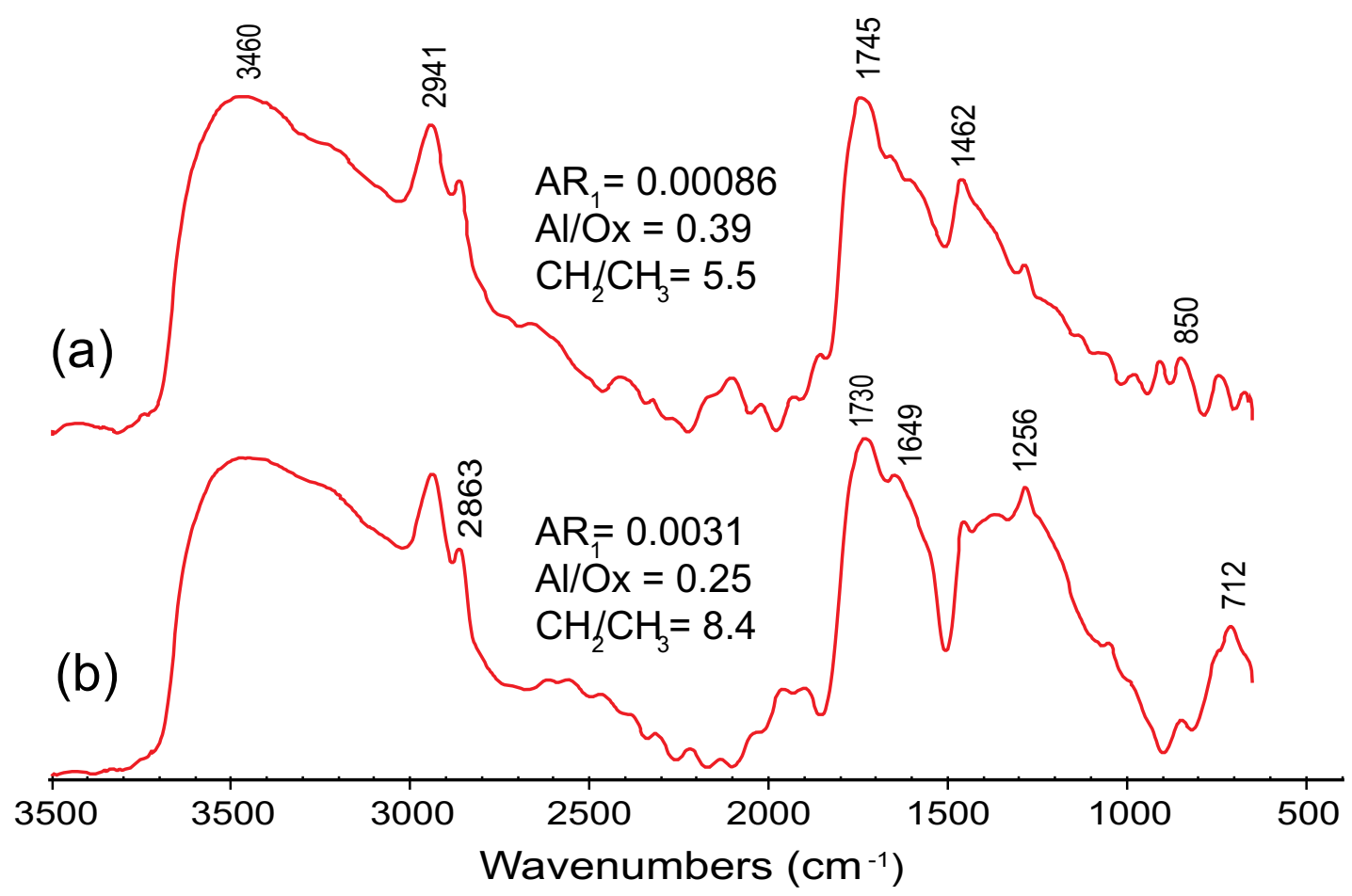

Figure 9. Monoletes prepollen grain. Micro-FTIR spectra. (a) and (b) Two sample locations on one grain. 


\section{ACKNOWLEDGEMENTS}

We are very much indebted to Katherine Jones (Biology Department, Cape Breton University) for the use of research microscopes, and to the Natural Science and Engineering Research Council of Canada for generous financial support to ELZ. Deb DeChurch (Indiana Geological and Water Survey, Bloomington) edited an earlier manuscript, and the journal reviewers, one anonymous, the other J. Hilton (University of Birmingham), and R. Fensome (co-editor, Atlantic Geology) are cordially thanked for their efforts that not only focused the technical content, but also improved its stylistic presentation.

\section{REFERENCES}

Bell, W.A. 1938. Fossil flora of Sydney Coalfield, Nova Scotia. Geological Survey of Canada, Memoir 215, Ottawa, 334 p. https://doi.org/10.4095/101646

Berner, R.A. 1980. Early diagenesis. Princeton University Press, $241 \mathrm{p}$.

Birk, D. 1990. Quantitative coal mineralogy of the Sydney Coalfield, Nova Scotia, Canada, by scanning electron microscopy, computerized image analysis, and energy-dispersive X-ray spectrometry. Canadian Journal of Earth Sciences, 27, pp. 163-179. https://doi.org/10.1139/e90$\underline{017}$

Chen Y., Zou C., Mastalerz, M., Hu S., Gasaway, C., and Toa X. 2015. Applications of micro-Fourier transform infrared spectroscopy (FTIR) in the geological sciences. A review. International Journal of Molecular Sciences, 15, pp. 30223-30255. https://doi.org/10.3390/ijms161226227

Cleal, C.J. and Zodrow, E.L. 1989. Epidermal structure of some medullosan Neuropteris foliage from the Middle and Upper Carboniferous of Canada and Germany. Palaeontology, 32, pp. 837-882.

Colthup, N.B., Daly, L.H., and Wiberley, S.S. 1990. Introduction to infrared and Raman spectroscopy. Academic Press, New York, 547 p.

Cridland, A.A., Morris, J.E., and Baxter, R.W. 1963. The Pennsylvanian plants of Kansas and their stratigraphic significance. Palaeontographica Abteilung B, 112, pp. $59-92$.

D’Angelo, J.A. 2006. Analysis by Fourier transform infrared spectroscopy of Johnstonia (Corystospermales, Corystospermaceae) cuticles and compressions from the Triassic of Cacheuta, Mendoza, Argentina. Ameghiniana, 43, pp. 669-685.

D’Angelo, J.A. and Zodrow, E.L. 2015. Chemometric study of structural groups in medullosalean foliage (Carboniferous, fossil Lagerstätte, Canada): chemotaxonomic implications. International Journal of Coal Geology, 138, pp. 42-54. https://doi.org/10.1016/j.coal.2014.12.003

D’Angelo, J.A. and Zodrow, E.L. 2016. 3D chemical map and a theoretical life model for Neuropteris ovata var. simonii (index fossil, Asturian, Late Pennsylvanian, Canada).
International Journal of Coal Geology, 153, pp. 12-27. https://doi.org/10.1016/j.coal.2015.11.007

Deer, W.A., Howie, R.A., and Zussman, J. 1992. The rock-forming minerals. Second edition. Longman and Group (FE) Ltd., Hong Kong, 696 p.

Dennis, R.L. and Eggert, D.A. 1978. Parasporotheca, gen. nov., and its bearing on the interpretation of the morphology of permineralized medullosan pollen organs. The Botanical Gazette, 139, pp. 117-139. https://doi. org $/ 10.1086 / 336978$

Gillespie, W.H. and Clendening, J.A. 1967. West Virginia plant fossils, I. Dolerotheca and Daubreeia. West Virginia Academy of Science, Geology and Mining Section, 38, pp. 159-168.

Grist, A.M., Ryan, R.J., and Zentilli, M. 1995. The thermal evolution and timing of hydrocarbon generation in the Maritimes Basin of eastern Canada: evidence from apatite track data. Canadian Society of Petroleum Geologists Bulletin, 43, pp. 145-155.

Halle, T.G. 1933. The structure of certain fossil spore-bearing organs believed to belong to pteridosperms. Kunglia Svenska Vetenskapsakademiens Handlingar, Tredje Serien, Band 12 (6), Stockholm Almqvist \& Wiksells Boktryckeri, A.B., 103 p., pl. 1-15.

Krumbein, W.C. and Garrels, R.M. 1952. Origin and classification of chemical sediments in terms of $\mathrm{pH}$ and oxidation-reduction potentials. Journal of Geology, 60, pp. 1-33. https://doi.org/10.1086/625929

Lis, G.P., Mastalerz, M., Schimmelmann, A., and Stankiewicz, B.A. 2005. FTIR absorption indices for thermal maturity in comparison with vitrinite reflectance Ro in type-II kerogens from Devonian black shales. Organic Geochemistry, 36, pp. 1533-1552. https://doi.org/10.1016/j.orggeochem.2005.07.001

Mastalerz, M. and Bustin, R.M. 1993. Electron microprobe and micro-FTIR analyses applied to maceral chemistry. International Journal of Coal Geology, 24, pp. 333-345. https://doi.org/10.1016/0166-5162(93)90018-6

Millay, M.A. and Taylor, T.N. 1979. Paleozoic seed fern pollen organs. The Botanical Review, 45, pp. 301-375. https://doi.org/10.1007/bf02860858

Nicholls, G.D. 1968. The geochemistry of coal-bearing strata. In Coal and coal-bearings strata. Edited by D. Murchison and T.S. Westoll. Elsevier, New York, pp. 269-307. https://doi.org/10.2307/1795148

Pacyna, G. and Zdebska, D. 2010. Upper Carboniferous seed fern (Pteridospermophyta) pollen organs from Silesia (Poland), and related evolutionary considerations. Łodz Monographiae Botanicae, 100, 51 p. https://doi. org $/ 10.5586 / \mathrm{mb} .2010 .001$

Pacyna, G. and Zdebska, D. 2012. Carboniferous plants preserved within siderite nodules - a remarkable state of preservation providing a wealth of information. Acta Palaeobotanica, 52, pp. 247-269.

Peterson, H.I., Rosenberg, P., and Nytoft, H.P. 2008. Oxygen groups in coals and alginite-rich kerogen revisited. International Journal of Coal Geology, 74, pp. 93-113. https:// 
doi.org/10.1016/j.coal.2007.11.007

Renault, B. 1896. Bassin houiller et permien d'Autun et d'Épinac. Flore fossile pt. 2 Étude Gîtes Mineral de France. Fascicule IV (Texte), Ministere des Travaux Publics. Imprimerie Nationale, Paris. https://doi.org/10.1017/ $\underline{\text { s0016756800187412 }}$

Rochdi, A. and Landais, P. 1991. Transmission micro-infrared spectroscopy: an efficient tool for microsample characterization of coal. Fuel, 70, pp. 367-371. https://doi. org/10.1016/0016-2361(91)90124-s

Rothwell, G. W. and Eggert, D.A. 1986. A monograph of Dolerotheca Halle, and related complex permineralized medullosan pollen organs. Transactions of the Royal Society of Edinburgh: Earth Sciences, 77, pp. 47-79. https:// doi.org/10.1017/s0263593300099995

Schopf, J.M. 1936 The paleobotanical significance of plant structure in coal. Transactions of the Illinois Academy of Science, 28(2), pp. 106-110.

Schopf, J.M. 1948. Pteridosperm male fructifications: American species of Dolerotheca, with notes regarding certain allied forms. Journal of Palaeontology, 22, pp. 681-724.

Schopf, J.M. 1975. Modes of fossil preservation. Review of Palaeobotany and Palynology, 20, pp. 27-53. https://doi. org/10.1016/0034-6667(75)90005-6

Stidd, B.M. 1981. The current status of medullosan seed ferns. Review of Palaeobotany and Palynology, 32, pp. 63-101. https://doi.org/10.1016/0034-6667(81)90075-0

Stidd, B.M. 1990. Further documentation of the structure of Dolerotheca and a critique of other theories. Palaeontographica B, 217, pp. 51-86.

Stidd, B.M., Leisman, G.A., and Phillips,T.L. 1977. Sullitheca dactylifera gen. et sp. nov.: A new medullosan pollen organ and its evolutionary significance. American Journal of Botany, 64, pp. 994-1002. https://doi. org/10.1002/j.1537-2197.1977.tb11945.x

Walker, R. and Mastalerz, M. 2004. Functional group and individual maceral chemistry of high volatile bituminous coals from southern Indiana: controls on coking. International Journal of Coal Geology, 58, pp. 181-191. https:// doi.org/10.1016/j.coal.2003.10.008

Wang, S. H. and Griffiths, P. R. 1985. Resolution enhancement of diffuse reflectance i.r. spectra of coals by Fourier self-deconvolution. 1. C-H stretching and bending modes. Fuel 64, pp. 229-236. https://doi.org/10.1016/00162361(85)90223-6

Zodrow, E.L. 2002. The "medullosalean forest" at the Lloyd Cove Seam (Pennsylvanian), Sydney Coalfield, Nova Scotia, Canada. Atlantic Geology, 38, pp. 177-195. https:// doi.org/10.4138/1261

Zodrow, E.L. 2004. Plant-fossils of Sydney Coalfield, collector E.L. Zodrow Curatorial document, Cape Breton Uni- versity, XII, pp. 1098-1130.

Zodrow, E.L. and D’Angelo, J.A. 2013. Digital compression maps: an improved method for studying Carboniferous foliage. Atlantic Geology, 49, pp. 126-130. https://doi. org/10.4138/atlgeol.2013.006

Zodrow, E.L. and Mastalerz, M. 2009. A proposed origin for fossilized Pennsylvanian plant cuticles by pyrite oxidation (Sydney Coalfield, Nova Scotia, Canada). Bulletin of Geosciences, 84, pp. 227-240. https://doi.org/10.3140/ bull.geosci.1094

Zodrow, E.L. and Mastalerz, M. 2017. Rodlets from compressed medullosalean plant fossils: chemical and morphological studies (Late Pennsylvanian Sydney Coalfield, Canada). Folia, 51, pp. 23-30. https://doi.org/10.1515/ fbgp-2017-0003

Zodrow, E.L. and Mastalerz, M. 2018. A study of functional groups of trichomes of Odontopteris cantabrica: implications for molecular taxonomy (seed ferns, Carboniferous, Canada). International Journal of Coal Geology, 198, pp. 77-87. https://doi.org/10.1016/j.coal.2018.09.005

Zodrow, E.L., D’Angelo, J.A., Mastalerz, M., and Keefe, D. 2009. Compression-cuticle relationship of seed ferns: Insights from liquid-solid states FTIR (late Palaeozoic-early Mesozoic, Canada-Spain-Argentina). International Journal of Coal Geology, 79, pp. 61-73. https:// doi. org/10.1016/j.coal.2009.06.001

Zodrow, E.L., Helleur, R., Werner-Zwanziger, U., Banghao Chen, and D'Angelo, J.A. 2013. Spectrochemical study of Trigonocarpus grandis (Pennsylvanian tree-fern ovule, Canada): implications for fossil-organ linkage. International Journal of Coal Geology, 109-110, pp. 24-35. https://doi.org/10.1016/j.coal.2013.01.013

Zodrow, E.L., D’Angelo, J.A., Taylor, W.A., Catelani, T., Heredia-Huerrero, J.A., and Mastalerz, M. 2016. Secretory organs: implications for lipoid taxonomy and kerogen formation (seed ferns, Pennsylvanian, Canada). International Journal of Coal Geology, 167, pp. 184-200. https:// doi.org/10.1016/j.coal.2016.10.004

Zodrow, E.L., Mastalerz, M., Pšenička, J., and Cleal, C.J. 2017a. Linking Dolerotheca-like prepollen organs with Alethopteris pseudograndinioides foliage and assessing chemical properties of in situ prepollen grains: Implications for reconstructing Pennsylvanian-age alethopterid seed ferns. International Journal of Coal Geology, 183, pp. 65-77. https://doi.org/10.1016/j.coal.2017.08.004

Zodrow, E.L., D'Angelo, J.A., and Cleal, C.J. 2017b. 3D chemometric model and frond architecture of Alethopteris ambigua (Medullosales): implications for reconstruction and taxonomy. Palaeontographica Abt. B, 295, pp. 91133. https://doi.org/10.1127/palb/295/2017/91

Editorial responsibility: Robert A. Fensome 